\title{
Pengolahan Limbah Cair Rumah Sakit dengan Metode Lahan Basah Buatan (Constructed Wetland) dan Tanaman Air Typha latifolia
}

\section{Hospital Wastewater Treatment Using The (Constructed Wetland) Method and Typha latifolia Water Plant}

\author{
Amrul Hasan ${ }^{1}$, Suryani Catur Suprapti ${ }^{2}$ \\ ${ }^{1}$ Jurusan Kesehatan Lingkungan, Politeknik Kesehatan Tanjung Karang, Indonesia \\ ${ }^{2}$ Jurusan Teknik Gigi, Politeknik Kesehatan Tanjung Karang, Indonesia
}

\section{ARTICLE INFO}

\section{Article history}

Received date

05 Oct 2021

Revised date

09 Nov 2021

Accepted date

22 Nov 2021

Keywords:

Constucted wetlands; Typha latifolia;

Wastewater.

\section{Kata kunci:}

Lahan basah buatan;

Typha latifolia;

Limbah.

\begin{abstract}
ABSTRAK
Utilization of the aquatic plant Typha latifolia, in the treatment of hospital wastewater with the method of an artificial wetland system (constructed wetland), is expected to be able to treat the liquid waste of health care facilities. This study aims to determine the ability of the aquatic plant Typha latifolia in degrading the parameters contained in the wastewater of health facilities using the Artificial Wetland Method. Quasi-experimental research design. The measurement of liquid waste parameters (BOD, COD, TSS, Fatty Oil, and Ammonia) is carried out by taking samples at the inlet and outlet of each pot, then analyzed in the laboratory. The study reported an average influent BOD level of $66.2 \mathrm{mg} / \mathrm{L}$, an average effluent in a circular cross-sectional pot increased by $99.6 \mathrm{mg} / \mathrm{L}$, an influent COD level of $190.8 \mathrm{mg} / \mathrm{L}$, an effluent in a rectangular pot four decreased by an average of $31.6 \mathrm{mg} / \mathrm{L}$, the influent TSS parameter was $106 \mathrm{mg} / \mathrm{L}$, the average effluent in a circular cross-sectional pot was $283.6 \mathrm{mg} / \mathrm{L}$, the influent Oil \& Fat parameter averaged $1.2 \mathrm{mg} / \mathrm{L}$, average effluent $1.2 \mathrm{mg} / \mathrm{L}$, ammonia influent parameter $12 \mathrm{mg} / \mathrm{L}$, effluent $2.62 \mathrm{mg} / \mathrm{L}$. The rectangular cross-section has a good ability compared to other crosssections in reducing hospital waste, namely; $\mathrm{BOD}=64 \%, \mathrm{COD}=40 \%, \mathrm{TSS}=48 \%$, Ammonia $=67 \%$, Oil and Fat parameters did not decrease because the influent parameter levels were already below the Liquid Waste quality standard. The researcher concluded that the rectangular cross-sectional pot planted with Typha latifolia could reduce the wastewater parameters better than other cross-sectional types.
\end{abstract}

Corresponding Author:

Amrul Hasan

Jurusan Kesehatan Lingkungan, Politeknik Kesehatan Tanjung Karang, Indonesia Email: amrulhasan@gmail.com 


\section{PENDAHULUAN}

Limbah cair rumah sakit merupakan sumber pencemaran air yang potensial, karena mengandung senyawa organik dan Kimia yang cukup tinggi, yang dapat menyebabkan pencemaran badan air dan mikro-organisme patogen penyebab penyakit pada masyarakat sekitar (Said, 2013). Dampak potensial dari limbah air rumah sakit terhadap kesehatan masyarakat sangat besar, maka setiap rumah sakit di wajibkan mengolah limbah cair sehingga memenuhi potu mutu yang ditetapkan sebelum di buang ke badan air penerima (Said,2013). Untuk memenuhi standar Potu mutu yang ditetapkan, membutuhkan teknologi yang tepat untuk proses air limbah. Salah satu teknologi pengolahan air limbah yang telah digunakan adalah lahan basah buatan Constucted Wetlands (CWS) (UNHABITAT, 2008).

Lahan Basah buatan (Constucted Wetlands) dalah sistem pengolahan limbah cair yang dirancang dan dibangun menggunakan proses alami yang melibatkan vegetasi lahan basah, media, dan mikroorganisme, untuk meningkatkan kualitas air dan mengurangi efek berbahaya dari limbah, serta berkontribusi terhadap upaya konservasi air (UN-HABITAT, 2008). Wetland merupakan tiruan dari lahan basah alami seperti rawa-rawa, padang rumput basah, pasang surut yang terkena tanah, dataran banjir, dan lahan basah di sepanjang alur sungai (UN-HABITAT, 2008). Penggunaan macrophytes untuk pengolahan air limbah diperkenalkan oleh Käthe Seidel dari Jerman pada 1950-an, dengan metode yang di kenal sebagai aliran sub-permukaan horizontal. Reinhold Kickuth, melakukan penyempurnaan dalam sistem ini, dan secara bertahap metode ini secara luas dikenal di Eropa (Vymazal, 2005).

Pemanfaatan lahan basah buatan dalam pengolah limbah, telah diadopsi di Rumah Sakit Dhulikhel yang dibangun pada tahun 1997 (UNHABITAT, 2008). lahan basah buatan tidak hanya digunakan untuk membersihkan air sungai tercemar sebanyak 634.000 galon per hari, tetapi juga mampu meningkatkan kualitas air kelas IV (cocok untuk irigasi lanskap) untuk Kelas II (cocok untuk kontak manusia) dan hanya menggunakan proses biologi (Landscape seri kinerja). Selain itu, aplikasi untuk lansekap membuat Houtan park menjadi ruang publik yang lebih menyenangkan. Metode Constucted Wetlands memiliki kelebihan dibanding metode lainnya yaitu biaya operasional rendah,
Penelitian bertujuan mengetahui kemampuan tanaman air (Typha Latifolia) dalam pengolahan limbah cair rumah sakit (pH, BOD, COD, TSS, Minyak \& Lemak, Amoniak) pada 3 jenis penampang pot lahan basah buatan

\section{METODE}

Penelitian ini menggunakan desain eksperimental semu (quasi). Desain eksperimental yang digunakan dalam penelitian ini adalah mengambil dan memeriksa sampel sebelum perlakuan (melewati jenis penampang pot lahan basah buatan), dan setelah perlakuan pada masing-masing effluen pot lahan basah buatan. Selisih hasil pemeriksaan sampel pada influen dan effluen menunjukkan kemampuan tanaman air berdasarkan jenis penampang pot lahan basah buatan dalam menurunkan parameter limbah cair rumah sakit.

Penelitian ini telah melewati kaji etik dan mendapatkan Persetujuan Etik dari Komite Etik Penelitian Kesehatan Politeknik Kesehatan Tanjung Karang Nomor 251/EA/KEPKTJK/VIII/2019.

Penelitian dilaksanakan di IPAL RSD Kota Bandar Lampung. Sampel dalam penelitian ini adalah limbah cair rumah sakit sebelum melewati pot lahan basah buatan (influen) dan setelah melewati pot lahan basah buatan (effluen) pada tiap jenis penampang pot lahan basah buatan. Penentuan jumlah sampel berdasarkan Supranto J (2000). Sehingga jumlah sampel dalam penelitian ini adalah 20 sampel, setiap effluen pada masingmasing jenis pot diambil 5 kali ditambah 5 sampel influen. Parameter limbah cair yang di uji dalam penelitian ini adalah $\mathrm{pH}, \mathrm{BOD}, \mathrm{COD}$, TSS, Minyak \& Lemak, amonia, kemudian analisis di laboratorium. Metode Pengujian para meter $\mathrm{pH}$, BOD, COD, TSS, amonia sesuai dengan Standard Nasional Indonesia (SNI), sedangkan parameter Minyak \& Lemak menggunakan JIS No. 24 K-0102,1998. Teknik analisis data dilakukan dengan pendekatan kuantitatif untuk menentukan konsentrasi limbah yang mampu di turunkan oleh masing-masing jenis penampang pot, selanjutnya dibandingkan dengan Permen LHK No. P.68 2016 (Kementerian Lingkungan Hidup dan Kehutanan Republik Indonesia, 2016).

Kegiatan penelitian yang dilakukan selama lima bulan mulai dari 20 Agustus hingga 10 Desember 2019 di lokasi IPAL RSD. Kota Bandar Lampung. Kegiatan dimulai dengan pembuatan tiga jenis penampang pot lahan basah buatan, (Johanna, 2012; Prawira, 2015), mengisi 
dengan media tanaman (batu koral sungai berukuran $1-3 \mathrm{~cm}$ dan $3-5 \mathrm{~cm}$, kompos, dan arang tempurung kelapa) kemudian di tanami dengan tanaman air (Typha latifolia). (Johanna, 2012; Prawira, 2015),

Tanaman air (Typha latifolia) yang digunakan dalam penelitian ini adalah tanaman liar yang di ambil dari rawa-rawa pinggir pantai Kabupaten Lampung Selatan, kemudian ditanam di dalam ember berisi air selama satu bulan sebelum di tanam ke dalam pot lahan basah buatan. Jumlah tanaman pada masing-masing penampang pot lahan basah buatan berjumlah sama yaitu 24 rumpun Typha latifolia, dengan pembagian ke dalam masing-masing pot sebagai berikut: Delapan pot segi empat, masing-masing pot ditanami sebanyak tiga rumpun Typha latifolia, Dua pot persegi panjang tiap pot ditanami sebanyak 12 rumpun Typha latifolia. dan Enam buah pot bundar, tiap pot ditanami sebanyak empat rumpun Typha latifolia.

Selanjutnya dilakukan aklimatisasi tanaman selama 2 minggu, setelah di tanam. Aklimatisasi tanaman di pot lahan basah buatan dengan mengalirkan limbah cair secara bertahap ke dalam pot lahan basah buatan. Setelah tanaman tumbuh dengan baik, selanjutnya limbah cair di alirkan secara penuh dengan laju aliran sebesar 2liter/menit, penentuan laju aliran didasarkan hasil pengukuran pada masing-masing outlet masing-masing pot, sejak aliran masuk melalui inlet, mengisi permukaan pada semua jenis penampang Pot sampai aliran mengalir pada out-let masing-masing pot. Volume masingmasing penampang pot sebesar $1 \mathrm{~m}^{3}$, penentuan jumlah pot di dasarkan pada perhitungan sebagaimana di tampilkan pada tabel 1 .

Tabel 1. Jumlah Pot Lahan Basah Buatan berdasarkan Jenis Penampang

\begin{tabular}{|c|c|c|c|c|c|c|c|}
\hline \multirow{2}{*}{ Jenis Penampang } & \multicolumn{3}{|c|}{ Ukuran } & \multirow{2}{*}{ Volume } & \multirow{2}{*}{ Volume Total } & \multirow{2}{*}{$\begin{array}{c}\text { Jumlah } \\
\text { Pot }\end{array}$} & \multirow{2}{*}{ Pembulatan } \\
\hline & $\mathbf{P}$ & $\mathbf{L}$ & $\mathbf{T}$ & & & & \\
\hline Segi empat & 0,5 & 0,5 & 0,5 & 0,13 & 1,06 & 8,15 & 8 \\
\hline Segi panjang & 2 & 0,5 & 0,6 & 0,6 & 1,06 & 1,77 & 2 \\
\hline \multirow[t]{2}{*}{ Bundar } & $\pi$ & $r$ & $\mathrm{~T}$ & & & & \\
\hline & 3,14 & 0,3 & 0,6 & 0,17 & 1,06 & 6,24 & 6 \\
\hline
\end{tabular}

Tabel 2. Ketebalan Media pada Masingmasing Pot

\begin{tabular}{|c|c|c|c|}
\hline $\begin{array}{c}\text { Jenis Lapisan } \\
\text { media }\end{array}$ & $\begin{array}{c}\text { Segi } \\
\text { empat }\end{array}$ & $\begin{array}{c}\text { Segi } \\
\text { panjang }\end{array}$ & Bundar \\
\hline $\begin{array}{l}\text { Arang Batok } \\
\text { Kelapa }\end{array}$ & 0,05 & 0,05 & 0,05 \\
\hline $\begin{array}{l}\text { Ketebalan } \\
\text { Media Tanam } \\
\text { (Kompos) }\end{array}$ & 0,25 & 0,2 & 0,2 \\
\hline $\begin{array}{l}\text { Ketebalan } \\
\text { Koral ukuran } \\
(0,5-2 \mathrm{~cm})\end{array}$ & 0,15 & 0,05 & 0,05 \\
\hline $\begin{array}{l}\text { Ketebalan } \\
\text { Koral ukuran } \\
(2-4 \mathrm{~cm})\end{array}$ & 0,15 & 0,3 & 0,3 \\
\hline
\end{tabular}

Berdasarkan tabel 1 selanjutnya ditentukan ketebalan lapisan media tanam pada masing-masing pot, hasil penghitungan ditampilkan pada tabel 2.

Setelah diketahui jumlah pot dan ketebalan media pada masing-masing penampang, selanjutnya media disusun ke dalam pot dan ditanami dengan Typha latifolia. Jumlah tanaman pada masing-masing jenis penampang sebanyak 24 rumpun. Susunan jumlah pot masing-masing penampang sebagaimana ditampilkan pada Gambar 1. Susunan Pot Berdasarkan Jenis Penampang.

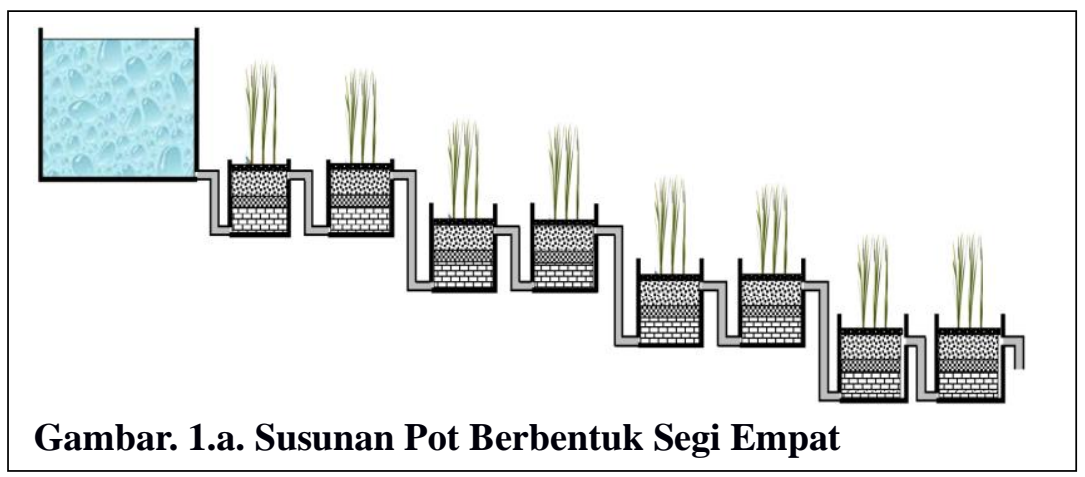



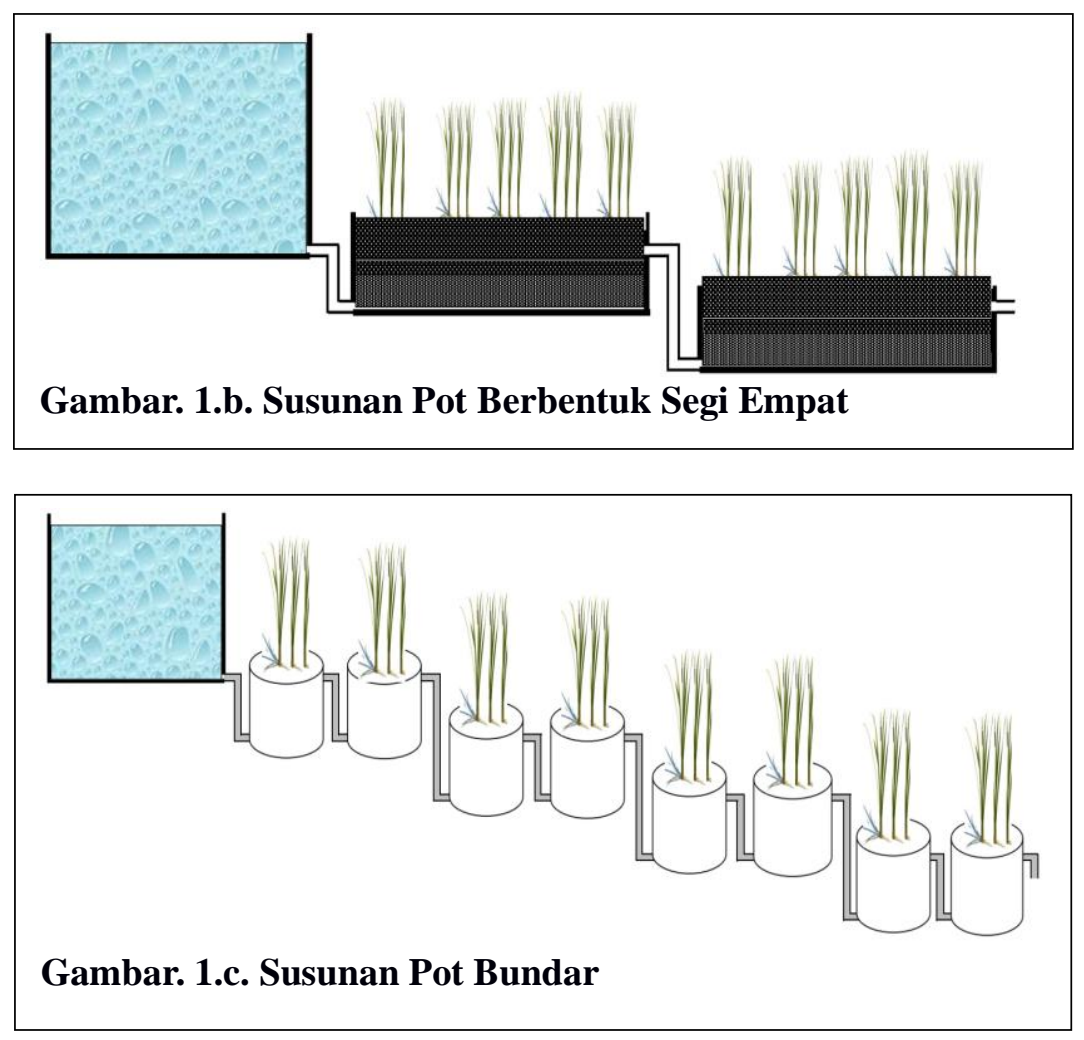

Proses Kerja penelitian dilakukan sebagai berikut: limbah cair di pompa dari bak equalisasi IPAL rumah sakit, di pompa menuju dua buah bak penampungan atas dengan mamsing-masing volume $1 \mathrm{~m}^{3}$, setelah bak penampungan atas terisi penuh kemudian di alirkan secara gravitasi menuju e jenis penampang pot, dengan membuka stop kran (masing-masing stop kran yang telah diberi tanda). Pengatur debit aliran di dapat dari hasil pengukuran di lapangan, (masing-masing stop kran yang telah diberi tanda). Selanjutnya air akan mengisi masing-masing pot yang telah ditanami Typha latifolia, sampai pada out-let masing-masing pot. Limbah cair dari outlet masing-masing penampang pot selanjutnya di tampung pada bak penampungan bawah yang dilengkapi dengan pompa yang bekerja secara otomatis akan memompa limbah cair ke dalam bak ekualisasi IPAL Gambar 2.

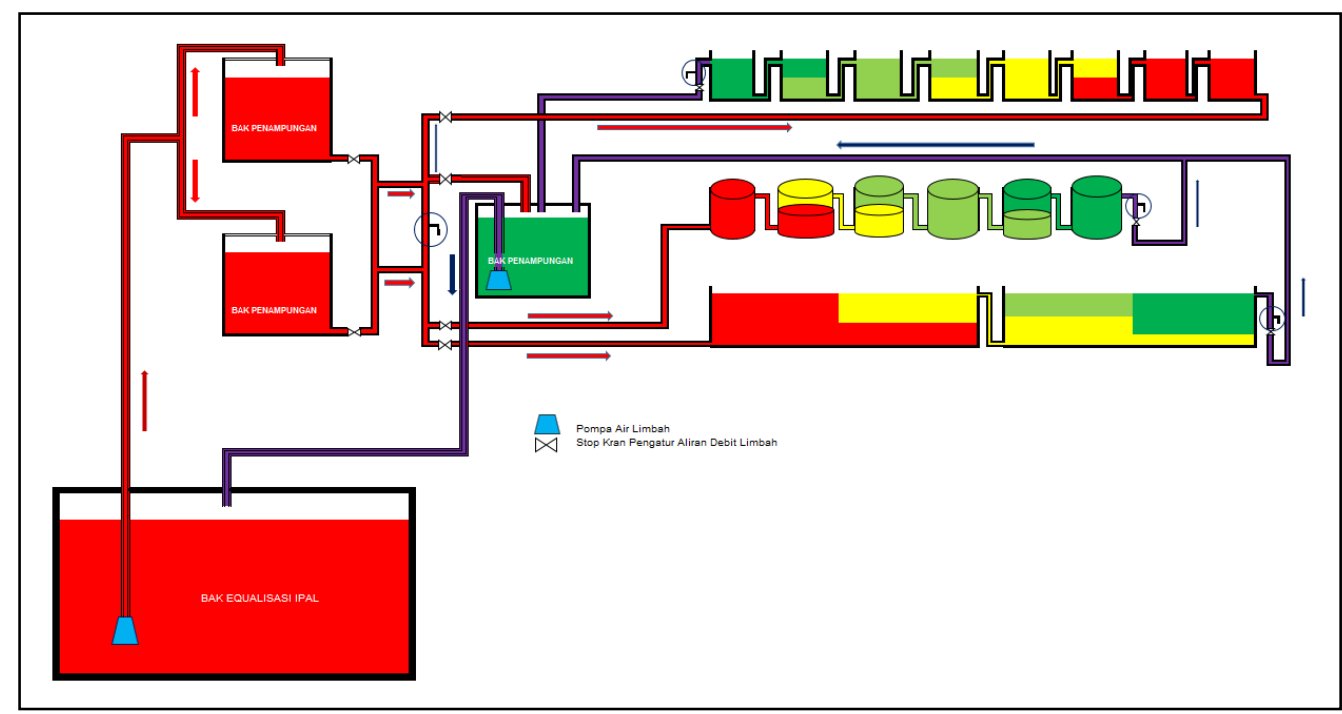

Gambar. 2. Instalasi Aliran Limbah Cair dari Pot Equalisasi IPAL melalui Masing-masing Jenis Penampang Pot Lahan Basah dan Dialirkan Kembali ke IPAL 


\section{HASIL}

\section{Parameter BOD}

Rata-rata kadar BOD influen sebesar $66,2 \mathrm{mg} / \mathrm{L}$, nilai minimum sebesar $51 \mathrm{mg} / \mathrm{L}$ dan nilai maksimum sebesar $85 \mathrm{mg} / \mathrm{L}$. Hasil analisis nilai rata-rata effluen pada pot penampang bundar mengalami kenaikan yaitu sebesar $99,6 \mathrm{mg} / \mathrm{L}$, nilai minimum sebesar $63 \mathrm{mg} / \mathrm{L}$ dan nilai maksimum $126 \mathrm{mg} / \mathrm{L}$.

Parameter BOD pada pot lahan basah buatan dengan penampang bundar selalu mengalami peningkatan dibandingkan dengan pot persegi dan persegi panjang. Sedangkan kadar BOD pada pot dengan penampang persegi panjang memiliki kecenderungan menurun dibandingkan dengan influen, sementara pot berbentuk persegi empat mengalami fluktuasi, kadang naik dan kadang turun dibandingkan dengan kadar BOD influen .

\section{Parameter COD}

Rata-rata kadar COD influen sebesar 190,8mg/L, nilai minimum sebesar $148 \mathrm{mg} / \mathrm{L}$ dan nilai maksimum sebesar $246 \mathrm{mg} / \mathrm{L}$. Rata-rata effluen pada pot segi empat mengalami penurunan dengan rata-rata sebesar $31,6 \mathrm{mg} / \mathrm{L}$, nilai minimum sebesar $18 \mathrm{mg} / \mathrm{L}$ dan nilai maksimum 50mg/L.

Kadar parameter COD pada pot lahan basah buatan, sejalan dengan parameter BOD, bahwa parameter COD pada penampang bundar selalu mengalami peningkatan dibandingkan dengan pot persegi dan persegi panjang. Sedangkan kadar COD pada pot dengan penampang persegi panjang memiliki kecenderungan menurun dibandingkan dengan influen, sementara pot berbentuk persegi empat mengalami fluktuasi, kadang naik dan kadang turun dibandingkan dengan kadar COD influen .

\section{Parameter TSS}

Rata-rata kadar parameter TSS influen sebesar $106 \mathrm{mg} / \mathrm{L}$, nilai minimum sebesar $20 \mathrm{mg} / \mathrm{L}$ dan nilai maksimum sebesar $218 \mathrm{mg} / \mathrm{L}$, setelah melewati pot lahan basah buatan yang ditanami dengan tumbuhanair Typha latifolia nilai ratarata effluen pada pot penampang bundar mengalami kenaikan dibandingkan dengan duajenis penampang pot lainnya yaitu rata-rata sebesar $283,6 \mathrm{mg} / \mathrm{L}$, nilai minimum sebesar $180 \mathrm{mg} / \mathrm{L}$ dan nilai maksimum $350 \mathrm{mg} / \mathrm{L}$.

Parameter TSS setelah melewati pot lahan basah buatan memiliki kecenderungan menurun dibandingkan dengan kadar parameter TSS pada influen, akan tetapi mengalami peningkatan pada pemeriksaan ke lima.

\section{Parameter Minyak \& Lemak}

Kadar parameter Minyak \& Lemak influen rata-rata sebesar $1,2 \mathrm{mg} / \mathrm{L}$, nilai minimum sebesar $1 \mathrm{mg} / \mathrm{L}$ dan nilai maksimum sebesar $2 \mathrm{mg} / \mathrm{L}$, dan rata-rata effluen setelah melewati pot penampang bundar mengalami kenaikan dengan rata-rata sebesar $1,2 \mathrm{mg} / \mathrm{L}$, nilai minimum sebesar $1 \mathrm{mg} / \mathrm{L}$ dan nilai maksimum $2 \mathrm{mg} / \mathrm{L}$. Artinya tidak ada pengaruh perlakuan terhadap parameter minyak \& lemak setelah melewati ke tiga jenis penampang lahan basah buatan dengan tumbahan air (Typha latifolia)

Hasil analisis limbah cair rumah sakit parameter minyak \& lemak setelah melewati tiga jenis penampang pot lahan basah buatan mengalami penurunan dibandingkan dengan kadar parameter minyak \& lemak pada influen, akan tetapi mengalami peningkatan pada pemeriksaan ke lima.

\section{Parameter Amoniak}

Kadar parameter amoniak influen sebesar $12 \mathrm{mg} / \mathrm{L}$, nilai minimum sebesar $1 \mathrm{mg} / \mathrm{L}$ dan nilai maksimum sebesar $25 \mathrm{mg} / \mathrm{L}$. Hasil analisis nilai rata-rata effluen pada jenis pot penampang bundar mengalami penurunan dengan rata-rata sebesar $2,62 \mathrm{mg} / \mathrm{L}$, nilai minimum sebesar $0,1 \mathrm{mg} / \mathrm{L}$ dan nilai maksimum $5 \mathrm{mg} / \mathrm{L}$. Setelah melewati tiga jenis penampang pot lahan basah buatan mengalami penurunan dibandingkan dengan kadar parameter amoniak pada influen, akan tetapi mengalami peningkatan pada pemeriksaan kelima.

Efisiensi penurunan parameter limbah cair rumah sakit pada ketiga jenis penampang pot lahan basah buatan diketahui dengan dilakukan uji anova satu arah. Uji anova dilakukan jika memenuhi asumsi, bahwa data berdistribusi normal. Berdasarkan hasil uji normalitas diketahui parameter limbah cair rumah sakit yang berdistribusi normal adalah BOD, COD, TSS, dan amoniak. Sedangkan parameter Minyak \& Lemak berdistribusi tidak normal. Parameter limbah cair rumah sakit yang berdistribusi normal dilanjutkan dengan Uji ANOVA, sedangkan parameter limbah cair rumah sakit yang berdistribusi tidak normal dilakukan uji Kruskal Wallis. 


\section{Parameter Biological Oxygen Demand (BOD)}

Pada hasil bahwa rata-rata kadar BOD berfluktuasi berdasarkan jenis penampang lahan basah buatan. Pot lahan basah buatan berbentuk Segi empat rata-ratanya adalah $0,014 \mathrm{ppm}$, pot lahan basah buatan berbentuk persegi panjang rata-ratanya adalah $0,112 \mathrm{ppm}$, dan pot lahan basah buatan berbentuk bundar rata-ratanya adalah -0,526. hasil uji anova memperlihatkan bahwa ada perbedaan yang bermakna pada rata- rata kadar BOD menurut jenis penampang pot lahan basah buatan (nilai $p$-value 0,025). Analisis lebih lanjut memperlihatkan bahwa tidak ada perbedaan kadar BOD antara pot segi empat dengan pot persegi panjang (nilai $p$-value 0,893 ), dan Pot bundar dengan pot segi empat (nilai $p$ value 0,066). Ada perbedaan kadar BOD antara pot penampang bundar dengan pot persegi panjang(nilai $p$-value 0,030 ). Hasil analisis anova satu arah parameter BOD di sajikan pada tabel 3.

Tabel 3. Hasil Analisis Anova Satu Arah Parameter BOD pada Jenis Penampang Pot

\begin{tabular}{|c|c|c|c|c|c|c|c|}
\hline \multicolumn{8}{|c|}{ Analysis of Variance } \\
\hline Source & \multicolumn{2}{|c|}{ SS } & \multicolumn{2}{|c|}{ df } & MS & $\mathbf{F}$ & Prob $>$ F \\
\hline Between groups & \multicolumn{2}{|c|}{1,18041333} & \multicolumn{2}{|l|}{2} & 0,590206667 & \multirow[t]{2}{*}{5,08} & \multirow[t]{2}{*}{0,0252} \\
\hline Within groups & \multicolumn{2}{|c|}{1,39392} & \multicolumn{2}{|l|}{12} & 0,11616 & & \\
\hline Total & \multicolumn{2}{|c|}{2,57433333} & 14 & & \multicolumn{3}{|l|}{0,183880952} \\
\hline \multicolumn{8}{|c|}{ Bartlett's test for equal variances: $\operatorname{chi} 2(2)=0,5435$ Prob>chi $2=0,762$} \\
\hline \multicolumn{8}{|c|}{ Tukey } \\
\hline BOD & Contrast & Std. Err. & $\mathbf{t}$ & $\mathbf{P}>\mathbf{t}$ & \multicolumn{3}{|c|}{ Tukey [95\% Conf. Interval] } \\
\hline \multicolumn{8}{|l|}{ Perlakuan } \\
\hline 2 vs 1 & 0,098 & 0,2155551 & 0,45 & 0,893 & $-0,4770716$ & \multicolumn{2}{|c|}{6730716} \\
\hline 3 vs 1 & $-0,54$ & 0,2155551 & $-2,51$ & 0,066 & $-1,115072$ & \multicolumn{2}{|c|}{,0350716 } \\
\hline 3 vs 2 & $-0,638$ & 0,2155551 & $-2,96$ & 0,030 & $-1,213072$ & \multicolumn{2}{|c|}{$-0,0629284$} \\
\hline
\end{tabular}

\section{Paremater Chemical Oxygen Demand (COD)}

Pada hasil di atas terlihat bahwa rata-rata kadar COD berfluktuasi berdasarkan jenis penampang lahan basah buatan. Pot lahan basah buatan berbentuk segi empat rata-ratanya adalah 0,034ppm, pot lahan basah buatan berbentuk persegi panjang rata-ratanya adalah $0,126 \mathrm{ppm}$, dan pot lahan basah buatan berbentuk bundar rata-ratanya adalah $-0,508$. hasil uji anova memperlihatkan bahwa ada perbedaan yang bermakna pada rata-rata kadar BOD menurut jenis penampang pot lahan basah buatan (nilai $p$ value 0,0258). Analisis lebih lanjut memperlihatkan tidak ada perbedaan rata-rata kadar COD antara pot Persegi Panjang dengan pot persegi empat (nilai p-value 0,906), dan Pot Bundar dengan pot segi empat $(0,066)$, ada perbedaan rata-rata kadar COD antara pot persegi panjang dan pot penampang bundar $(0,031)$. Hasil analisis anova satu arah parameter COD di sajikan pada tabel 4.

Tabel 4. Hasil Analisis Anova Satu Arah Parameter COD pada Jenis Penampang Pot

\begin{tabular}{|c|c|c|c|c|c|}
\hline \multicolumn{6}{|c|}{ Analysis of Variance } \\
\hline Source & SS & df & \multicolumn{2}{|c|}{ MS } & Prob $>$ F \\
\hline Between groups & 1,17364 & \multicolumn{2}{|l|}{2} & 0,58682 & 0,0258 \\
\hline Within groups & 1,39812 & 12 & \multicolumn{2}{|c|}{0,11651} & \\
\hline Total & 2,57176 & \multicolumn{3}{|c|}{$14 \quad 0,183697143$} & \\
\hline \multicolumn{6}{|c|}{ Tukey } \\
\hline COD & Contrast & Std. Err. & $\mathbf{t}$ & $P>t$ & Tukey $[95 \%$ Conf. Interval $]$ \\
\hline \multicolumn{6}{|l|}{ Perlakuan } \\
\hline 2 vs 1 & 0,092 & 0,2158796 & 0,43 & 0,906 & $-0,4839373-(-0,6679373)$ \\
\hline 3 vs 1 & $-0,542$ & 0,2158796 & $-2,51$ & 0,066 & $-1,117937-(-0,0339373)$ \\
\hline 3 vs 2 & $-0,634$ & 0,2158796 & $-2,94$ & 0,031 & $-(-0,0580627)$ \\
\hline
\end{tabular}

\section{Parameter Total Suspended Solid (TSS)}

Hasil Uji Kruskal-Wallis parameter TSS peringkat rata-rata kelompok perlakuan, di mana pot segi empat lebih tinggi nilainya dari pada pot persegi panjang sedangkan pot persegi panjang lebih tinggi dibandingkan dengan pot penampang bundar, nilai $p$-value uji Kruskal-Wallis adalah sebesar 0,7965 dimana lebih dari batas kritis 0,05 maka dapat disimpulkan bahwa ke tiga jenis pot lahan basah buatan tidak memberikan perbedaan bermakna dalam menurunkan parameter TSS. Hasil analisis TSS disajikan pada tabel 5. 


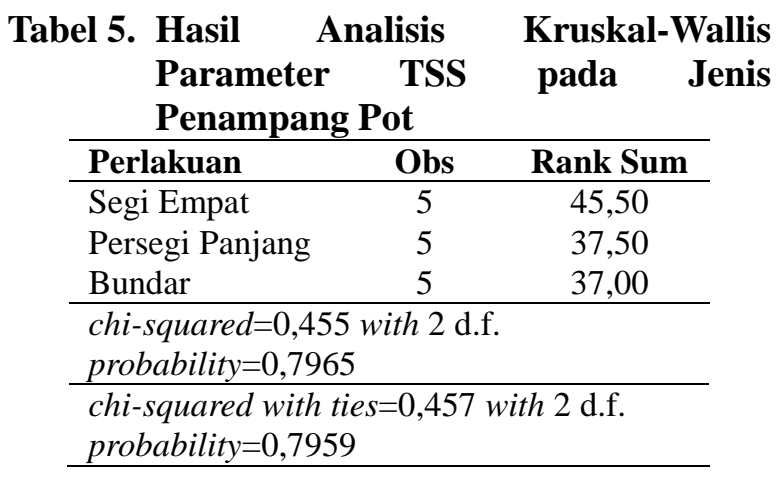

\section{Parameter Minyak dan Lemak}

Rata-rata kadar minyak dan lemak mengalami peningkatan berdasarkan jenis penampang lahan basah buatan. Pot lahan basah buatan berbentuk segi empat rata-ratanya adalah $0,100 \mathrm{ppm}$, pot lahan basah buatan berbentuk persegi panjang rata-ratanya adalah $-0,100 \mathrm{ppm}$, dan pot lahan basah buatan berbentuk bundar rata-ratanya adalah -0,300. Hasil uji anova memperlihatkan bahwa tidak ada perbedaan yang bermakna pada rata-rata kadar minyak dan lemak menurut jenis penampang pot lahan basah buatan (nilai p-value 0,903). Demikian juga pada analisis lebih lanjut memperlihatkan bahwa tidak ada perbedaan rata-rata kadar minyak dan lemak antara pot segi empat dengan pot persegi panjang, pot segi empat dengan pot penampang bundar, dan pot penampang bundar dengan pot persegi panjang. Hasil analisis disajikan pada tabel 6.

Tabel.6 Hasil Analisis Anova Satu Arah Parameter Minyak Lemak pada Jenis Penampang Pot

\begin{tabular}{|c|c|c|c|c|c|c|c|}
\hline \multicolumn{8}{|c|}{ Analysis of Variance } \\
\hline \multicolumn{2}{|c|}{ Source } & SS & df & $\mathbf{M s}$ & & $\mathbf{F}$ & Prob>F \\
\hline \multirow{2}{*}{\multicolumn{2}{|c|}{$\begin{array}{l}\text { Between groups } \\
\text { Within groups }\end{array}$}} & 0,133333333 & 2 & \multicolumn{2}{|c|}{0,066666667} & \multirow{2}{*}{0,19} & \multirow[t]{2}{*}{0,8290} \\
\hline & & 4,2 & 12 & & 0,35 & & \\
\hline \multicolumn{2}{|c|}{ Total } & 4,33333333 & 14 & \multicolumn{3}{|c|}{0,30952381} & \\
\hline \multicolumn{8}{|c|}{ Bartlett's test for equal variances: chi2 $2(2)=0,2052$ Prob $>$ chi $2=0,903$} \\
\hline \multicolumn{8}{|c|}{ Tukey } \\
\hline ML & Contrast & Std. Err. & $\mathbf{t}$ & $\mathbf{P}>\mathbf{t}$ & \multicolumn{3}{|c|}{ Tukey [95\% Conf. Interval] } \\
\hline \multicolumn{8}{|l|}{ Perlakuan } \\
\hline 2 vs 1 & $-9,12 \mathrm{e}-17$ & 0,3741657 & $-0,00$ & 1,000 & $-0,99$ & & 0,9982231 \\
\hline 3 vs 1 & $-0,2$ & 0,3741657 & $-0,53$ & 0,856 & $-1,1$ & & 0,7982231 \\
\hline 3 vs 2 & $-0,2$ & 0,3741657 & $-0,53$ & 0,856 & $-1,1$ & & 0,7982231 \\
\hline
\end{tabular}

\section{Parameter Amoniak}

Rata-rata kelompok perlakuan, di mana pot persegi panjang lebih tinggi nilainya dari pada pot penampang bundar sedangkan pot penampang bundar lebih tinggi dibandingkan dengan pot penampang bundar, nilai $\mathrm{p}$ uji kruskall wallis adalah sebesar 0,9827 di mana lebih dari batas kritis 0,05 maka dapat disimpulkan bahwa ke tiga jenis pot lahan basah buatan tidak memberikan perbedaan bermakna dalam menurunkan parameter amoniak.

Tabel 7. Hasil Kruskal-Wallis Parameter Amoniak pada Jenis Penampang Pot

\begin{tabular}{lcr}
\hline Perlakuan & Obs & Rank Sum \\
\hline Segi Empat & 5 & 39,00 \\
Persegi Panjang & 5 & 41,50 \\
Bundar & 5 & 39,50 \\
\hline chi-squared $=0,035$ with 2 d.f. \\
probability=0,9827 \\
\hline chi-squared with ties $=0,035$ with 2 d.f. \\
probability=0,9824 \\
\hline
\end{tabular}

\section{PEMBAHASAN}

Lahan basah buatan (Constructed wetlands) adalah salah satu metode pengolahan air limbah yang dirancang untuk pengolahan limbah cair agar tidak mencemari lingkungan. Penerapan yang digunakan dengan pemanfaatan tanaman air dalam proses pengolahan limbah cair secara alami (Vymazal. 2009). Proses dekomposisi limbah cair melalui media tanam, dan mikroorganisme serta gravitasi (Risnawati \& Damanhuri, 2009). Media tanam terdiri dari media (pasir, kerikil, atau media filter lainnya), tanaman air, atau mikroorganisme dan ekskreta (daun atau batang yang jatuh) (Kadlec \& Wallace, 2008).

Metode kerja lahan basah buatan yang dibangun memiliki dua jenis aliran, yaitu: pertama Free Water Surface (FWS), di mana air mengalir ke permukaan pusat tanaman; kedua adalah Subsurface Flow (SSF), dimana air melalui media tanaman. Alasan untuk memilih ke dua jenis pola aliran tersebut didasarkan atas fenomena alam, dimana pada musim hujan tanaman terendam air dan pada musim kemarau tidak tergenang (Usman \& Santosa, 2016). Tipe 
SSF dibagi menjadi dua jenis tergantung pada tren, yaitu Horizontal (HSSF) dan Vertical (VSSF) (Kadlec \& Wallace, 2008). Tanaman yang digunakan di lahan basah buatan adalah jenis tanaman air, tergantung di mana tanaman air hidup, mereka dapat dibagi menjadi 4 kelompok, yaitu tanaman yang baru muncul, tanaman daun terapung, tanaman terendam, dan tanaman mengambang bebas.

\section{Parameter BOD}

Hasil penelitian ini didapatkan bahwa penurunan parameter BOD setelah melalui pot lahan basah buatan mengalami fluktuasi pada pengukuran pertama kadar BOD pada semua jenis pot mengalami peningkatan berdasarkan jenis penampang pot lahan basah buatan, pada pot penampang segi empat mengalami sedikit peningkatan dibandingkan dengan pot dengan penampang bundar sementara pot penampang persegi panjang memiliki kecenderungan penurunan. Kadar BOD pada pot penampang bundar memiliki kecenderungan peningkatan. Hal ini terjadi karena adanya proses degradasi zat pencemar organik oleh mikroorganisme secara aerob. Sumber oksigen terlarut tersebut bersumber dari udara yang masuk ke dalam air limbah, penambahan media tanaman (kompos) mengakibatkan mikroorganisme pengurai zat organik dalam limbah cair rumah sakit membutuhkan oksigen lebih banyak yang berdampak pada tingginya, kadar BOD dalam masing-masing. Adanya perbedaan hasil pengukuran kadar BOD pada masing-masing pot kemungkinan terjadi karena perbedaan luas penampang pot. Selain itu juga adanya pengaruh cuaca yang sangat panas. Karathanasis, et al. (2003) mengemukakan, efisiensi penghilangan BOD yang diamati pada sistem cattail di musim semi, rata-rata di bawah 55\%, hal ini mungkin disebabkan jumlah biomassa di atas permukaan tanah lebih besar dari pada musim sebelumnya Karathanasis, et al. (2003). Hua, Zhao, dan Zeng (2013) mengemukakan bahwa porositas efektif akan berkurang karena akar tanaman akan menempati ruang pori, lapisan atas $(0-30 \mathrm{~cm})$ tempat akar tanaman terkonsentrasi Hua, G., Zhao dan Zeng (2013), Sementara Knowles, et al. (2011) menyatakan kehadiran akar tanaman akan menghambat pori saluran (memperluas substrat atau menghambat pemadatan pasir), yang mengakibatkan porositas efektif yang lebih besar.

Pengolahan limbah cair rumah sakit menggunakan metode Subsurface Flow Constructed Wetland dengan tumbuhan Typha latifolia (HSF-CW+Typha) ini terdapat media isian bahan padat (pasir) yang menyebabkan mikroorganisme yang terlibat tumbuh dan melekat atau membentuk lapisan tipis (biofilm) pada permukaan media (Tchobanoglous, Burton, \& Stensel, 2003). Limbah cair rumah sakit yang dialirkan melalui media tempat tumbuhnya mikroorganisme sebagai biofilter akan menghasilkan lapisan lendir yang menutupi media tumbuh atau disebut biological film dan akan mengalami proses penguraian secara biologis. Menurut Wood (dalam Tangahu, dan Warmadewanthi, 2001) bahwa penurunan zat organik dalam sistem lahan basah buatan terjadi karena adanya mekanisme aktivitas mikroorganisme dan tumbuhan, melalui proses oksidasi oleh potteri aerob yang tumbuh di sekitar rizhosfer tumbuhan maupun kehadiran potteri heterotrof dalam air limbah. Menurut Khiatuddin (2003) bahwa semakin banyak jaringan akar dalam tanah, maka makin luas zona rizhosfer yang terbentuk, sehingga kemampuan rawa untuk mendukung mikroorganisme semakin meningkat.

\section{Parameter COD}

Penurunan parameter COD setelah melalui pot lahan basah penampang persegi panjang, kemudian meningkat pada pengukuran ketiga selanjutnya mengalami penurunan kembali pada pengukuran keempat dan kelima, sementara pada pot penampang segi empat memiliki kecenderungan penurunan meskipun tidak terlalu signifikan dibandingkan dengan pot penampang persegi panjang. Pot penampang bundar justru sebaliknya mengalami peningkatan kadar COD di semua pengukuran 1 sampai 5 .

Fluktuasi kadar COD pada pot penampang bundar diduga karena kompos yang di tambahkan sebagai media tanam lebih banyak dibandingkan dengan penampang persegi empat dan persegi panjang, sehingga mempermudah penyumbatan oleh akar tanaman dan padatan tersuspensi yang terserap oleh akar tanam. Pembongkaran media untuk mengatasi penyumbatan baik oleh akar maupun oleh sludge yang terakumulasi juga menjadi penyebab terjadinya fluktuasi hasil pengukuran. Menurut Mukhlis (2003). Morfologi sistem perakaran dan batang tumbuhan Cattail mempunyai akar serabut yang lebih banyak dan lebih panjang. Batang, tumbuhan Cattail tidak mempunyai bentuk yang nyata, namun merupakan daun seperti gabus (Mukhlis, 2003).

Akar adalah bagian pokok nomor tiga (disamping batang dan daun) bagi tumbuhan. Akar bagi tum-buhan mempunyai tugas untuk memperkuat berdi-rinya tumbuhan, kemudian 
berfungsi untuk menyerap air dan zat-zat makanan yang terlarut di dalam air dari dalam tanah, mengangkut air dan zat-zat makanan ke tempat-tempat pada tubuh tumbuhan yang memerlukan dan kadang-kadang sebagai tem-pat penimbunan makanan.

Kelarutan unsur hara dipengaruhi oleh cairan tertentu yang berasal dari akar. Pengisapan unsur hara oleh tumbuhan merupakan hubungan yang erat an-tara akar dan tanah, dimana akar menghasilkan cairan-cairan tertentu sebagai ekskresi, dimana cairan tersebut dimanfaatkan oleh mikroba. Akar tumbuhan juga dapat meningkatkan aktivitas mikroba, melalui produksi organik karbon dan melepaskan subtansi seperti gula dan asam amino. Tumbuhan air juga dapat menstabilkan air limbah, menyerap dan menyimpan nutrien serta bau dari air limbah (Tanner dan Sukies, 1995 dalam Coleman, 2001).

Penelitian yang dilakukan oleh Eduardo de Aguiar do Couto, et al (2015 dalam Al Kholif, et al., 2017), rata-rata efisiensi penurunan angka COD mencapai $64 \%$ pada reaktor UASB dan $70 \%$ pada reaktor anaerob. Pengolahan air limbah domestik dengan teknologi Biofilter anaerob bermedia batu apung mampu menurunkan kadar COD sebesar $97 \%$. Kemampuan daya serap batu apung dan sebagai tempat tumbuh dan berkembang biaknya miktoorganisme berpengaruh besar terhadap nilai penyisihan kadar COD (Al Kholif, et al., 2017). Penyisihan COD bisa berkisar antara 76-95\% dari air limbah domestik yang bersumber dari aktivitas rumah tangga (Assayed, A., Chenoweth, J., Pedley, S., 2015). Penerapan pasir silika sebagai media filter dalam pengolahan limbah domestik yang diterapkan beberapa batch mampu menyisihkan pencemar COD hingga 90\% (Kang, Y., Mancl, K., Tuovinen, O., 2007).

Dengan sistem pengolahan yang murah dan mudah, maka pengolahan air limbah domestik untuk digunakan kembali dapat berkontribusi dalam pengembangan lingkungan maupun wilayah perkotaan (Eduardo de Aguiar do Couto, et al. (2015 dalam Al Kholif, et al. 2017).

\section{Parameter TSS}

Hasil penelitian menunjukkan konsentrasi awal TSS pada limbah cair rumah sakit sebesar $96 \mathrm{mg} / \mathrm{L}$ dan mengalami penurunan setelah melewati ke tiga jenis penampang pot lahan basah buatan.

Kadar TSS limbah cair rumah sakit mengalami penurunan yang cukup baik dibandingkan dengan kadar TSS influen. Penurunan kadar TSS setelah melewati pengolahan limbah cair rumah sakit dengan constructed wetland dengan tumbuhan Typha latifolia terjadi karena adanya filtrasi oleh media tanam (koral dan kompos) serta akar tanaman yang berkembang semakin banyak.

Pengolahan limbah rumah sakit dengan Constructed Wetland dengan tumbuhan Typha latifolia mampu menurunkan kadar TSS seiring dengan waktu bertumbuhnya tanaman di dalam lahan basah buatan, hal ini dimungkinkan oleh adanya proses penyaringan SS dan secara mekanis ketika air limbah tersebut melewati media/substrat, juga terjadi penyaringan oleh massa akar atau fauna air (Stowell, et al., 1980). Dengan terjadinya penurunan TSS ini, maka akan mengurangi kebutuhan oksigen terlarut pada pengolahan biologis berikutnya. Pengukuran kelima terjadi peningkatan kadar TSS pada penampang pot bundar karena dilakukan pembongkaran media tanam pada pot bundar karena terjadi penyumbatan (cloging) oleh akar tanaman dan endapan air limbah (sludge). Penyumbatan menyebabkan proses penyerapan oleh akar tanaman menjadi terganggu.

\section{Parameter Minyak \& Lemak}

Minyak dan lemak merupakan senyawa trigliserida dari gliserol. Konsentrasi minyak lemak limbah cair rumah sakit rata-rata yakni $1,2 \mathrm{mg} / \mathrm{L}$ dan sudah berada di bawah potu mutu yang telah ditentukan oleh Permen LHK No 68 tahun 2016 yaitu $5 \mathrm{mg} / \mathrm{L}$ (Kementerian Lingkungan Hidup dan Kehutanan Republik Indonesia). Pengolahan limbah rumah sakit dengan Constructed Wetland dengan tumbuhan Typha latifolia tidak memberikan dampak terhadap penurunan kadar Minyak dan lemak. Hal ini kemungnkinan disebabkan limbah cair rumah sakit memiliki kandungan minyak dan lemak yang rendah dibandingkan dengan limbah domestik. Menurut Stowell, et al., (1980) seiring dengan waktu bertumbuhnya tanaman di dalam lahan basah buatan dimungkinkan oleh adanya proses dekomposisi minyak dan lemak oleh mikroorganisme dalam air limbah dan secara mekanis ketika air limbah tersebut melewati media/substrat, juga terjadi penyaringan oleh massa akar atau fauna air.

\section{Parameter Amoniak}

Konsentrasi Amoniak yang terkandung limbah cair rumah sakit pada kondisi awal sebesar 25mg/L. Memiliki kecenderungan penurunan setelah dilakukan pengolahan dengan Constructed Wetland dengan Typha latifolia, 
dengan jenis penampang segi empat, persegi panjang dan penampang bundar. Peningkatan parameter Amoniak terjadi dengan bertambahnya waktu tinggal.

Kadar effluen amoniak mengalami penurunan dibandingkan dengan kadar amoniak influen. Penurunan kadar amoniak setelah melewati pengolahan limbah cair rumah sakit dengan constructed wetland dengan tumbuhan Typha latifolia terjadi karena adanya penyerapan nitrogen oleh tumbuhan (Typha latifolia), meskipun penghilangan senyawa nitrogen secara langsung oleh tumbuhan rawa relatif kecil (Gersberg, 1985), namun tumbuhan rawa mempunyai peran yang tidak langsung tetapi sangat penting dalam proses penghilangan nitrogen, yaitu menjadi tempat menempel mikro organisme dan memasok oksigen melalui rizosfer sehingga mendukung pertumbuhan potteri aerob. Sementara itu senyawa Amoniak $\left(\mathrm{NH}_{3}\right)$ dan ion amonium $\left(\mathrm{NH}_{4}^{+}\right)$yang terbentuk melalui penguraian oleh potteri dalam proses amonifikasi akan diasimilasikan oleh tumbuhan menjadi berbagai bentuk senyawa organic (Singleton, 1995). Menurut Hidayat (2006), batang, dahan dan daun tanaman air di dalam lahan basah buatan akan memperluas area penyerapan mikroorganisma oleh tanaman. Di bawah permukaan substrat pasir dan kerikil yang tergenang, akar tumbuhan mengeluarkan oksigen sehingga akan terbentuk zona akar dan zona oksigen, terjadi absorpsi nitrogen dan unsur pencemar untuk pertumbuhan tumbuhan.

\section{Keterbatasan Penelitian}

Penelitian ini belum sempurna, karena masih banyak keterbatasan yang tidak dapat penulis hindari sehingga memberikan hasil yang belum memuaskan. Beberapa keterbatasan yang penulis alami sebagai berikut: Adanya pupuk organik (kompos) yang di tambahkan di dalam pot lahan basah buatan, menyebabkan peningkatan terhadap kadar BOD dan COD pada masing-masing pot lahan basah buatan jika dibandingkan dengan kadar awal di influen. Terjadinya sumbatan (cloging) akibat terakumulasinya sludge dan akar tanaman yang sehingga aliran limbah menjadi terhambat dan perbaikan saluran yang tersumbat menyebabkan peningkatan kadar TSS dan amoniak, karena susunan lapisan media tanam menjadi berubah dan mengganggu aktivitas organisme dalam mendegradasi limbah cair.

\section{SIMPULAN}

Pot lahan basah buatan dengan penampang segi empat memiliki kemampuan yang baik dalam menurunkan parameter TSS, dan Amoniak, tetapi tidak mampu menurunkan parameter BOD5 dan COD yang terkandung pada limbah cair rumah sakit dapat diturunkan dengan sistem pengolahan Subsurface Flow Constructed Wetland dengan tanaman Typha latifolia.

Pot lahan basah buatan dengan penampang persegi panjang memiliki kemampuan menurunkan konsentrasi BOD5, COD, TSS, dan Amoniak yang terkandung pada limbah cair rumah sakit dapat diturunkan dengan sistem pengolahan Subsurface Flow Constructed Wetland dengan tanaman Typha latifolia.

Saran yang dapat disampaikan dalam penelitian ini adalah pot lahan basah buatan dengan penampang persegi panjang dapat diterapkan, karena mampu menurunkan kandungan BOD dan COD limbah cair rumah sakit.lebih baik dibandingkan dengan penampang pot liannya.

Metode lahan basah buatan menggunakan pot dapat diterapkan sebagai upaya pemanfaatan kembali limbah cair untuk mengairi tanaman air dalam pot bunga.

\section{DAFTAR PUSTAKA}

Al Kholif, M., \& Ratnawati, R. (2017). Pengaruh Beban Hidrolik Media dalam Menurunkan Senyawa Ammonia pada Limbah Cair Rumah Potong Ayam (RPA). WAKTU: Jurnal Teknik UNIPA, 15(1), 1-9.

Assayed, A., Chenoweth, J., \& Pedley, S. (2015). Assessing the efficiency of an innovative method for onsite greywater treatment: Drawer compacted sand filter-A case study in Jordan. Ecological Engineering, 81, 525-533.

Coleman, J., Hench, K., Garbutt, K., Sexstone, A., Bissonnette, G., \& Skousen, J. (2001). Treatment of domestic wastewater by three plant species in constructed wetlands. Water, air, and soil pollution, 128(3), 283-295.

Gersberg, R. M., Elkins, B. V., \& Goldman, C. R. (1985). Wastewater treatment by artificial 
wetlands. Water Science and Technology, 17(4-5), 443-450.

Hidayat, N., Padaga, M. C., \& Suhartini, S. (2006). Mikrobiologi industri. Yogyakarta: Penerbit Andi.

Hua, G., Zhao, Z., \& Zeng, Y. (2013). Effects of plant root on hydraulic performance of clogging process in subsurface flow constructed wetland. In EGU General Assembly Conference Abstracts (pp. EGU2013-3831).

Johanna, E. (2012). Pemanfaatan Lahan Basah Buatan dengan Menggunakan Tanaman Typha Latifiola Untuk Mengolah Limbah Cair Domestik. [Skripsi]. Depok: Program Studi Teknik Lingkungan, Universitas Indonesia.

Kadlec, R. H., \& Wallace, S. (2008). Treatment wetlands. CRC press.

Kang, Y. W., Mancl, K. M., \& Tuovinen, O. H. (2007). Treatment of turkey processing wastewater with sand filtration. Bioresource technology, 98(7), 1460-1466.

Karathanasis, A. D., Potter, C. L., \& Coyne, M. S. (2003). Vegetation effects on fecal bacteria, BOD, and suspended solid removal in constructed wetlands treating domestik wastewater. Ecological engineering, 20(2), 157-169.

Khiatuddin, M. (2003). Melestarikan sumber daya air dengan teknologi rawa buatan. Gadjah Mada University Press.

Knowles, P., Dotro, G., Nivala, J., \& García, J. (2011). Clogging in subsurface-flow treatment wetlands: occurrence and contributing factors. Ecological Engineering, 37(2), 99-112.

Mukhlis, M. (2003). Laju Serapan Tumbuhan Air Reed (Phragmites australis) Dan Cattail (Typha angustifolia) Dalam Sistem Constructed Wetland Untuk Menurunkan Cod Air Limbah. Jurnal Purifikasi, 4(2), 67-72.

Kementerian Lingkungan Hidup dan Kehutanan Republik Indonesia. (2016). Permen LHK No. P.68 Tahun 2016, Tentang Baku Mutu Air Limbah Domestik.

Prawira, J. (2015). Efektifitas Sistem Lahan Basah Buatan Sebagai Alternatif Pengolahan Limbah Domestik. [Tugas Akhir]. Kepulauan Riau: Universitas Maritim Raja Ali Haji.
Risnawati, I., \& Damanhuri, T. P. (2009). Penyisihan Logam Pada Lindi Menggunakan Constructed Wetland. [Skripsi]. Bandung: Institut Teknologi Bandung.

Said, Nusa Idaman, Dan Widayat, Wahyu. (2013). Teknologi Pengolahan Air Limbah Rumah Sakit Dengan Proses Biofilter Anaerob-Aerob. Pusat Teknologi Lingkungan, Deputi Bidang Teknologi Pengembangan Sumberdaya Alam Badan Pengkajian dan Penerapan Teknologi, http://kelair.bppt.go.id.

Singleton, D. M., \& Lengyel, Z. (Eds.). (1995). The age factor in second language acquisition: A critical look at the critical period hypothesis. Multilingual Matters.

Stowell, C. P., \& Lee, Y. C. (1980). Neoglycoproteins the preparation and application of synthetic glycoproteins. In Advances in carbohydrate chemistry and biochemistry (Vol. 37, pp. 225-281). Academic Press.

Supranto, J. (2000). Teknik Sampling untuk Survei dan Eksperimen. Jakarta: Penerbit PT Rineka Cipta.

Tangahu, B. V., \& Warmadewanthi, I. D. A. A. (2001). Pengelolaan limbah rumah tangga dengan memanfaatkan tanaman cattail (typha angustifolia) dalam sistem constructed wetland. Jurnal Purifikasi, 2(3), 127-132.

Tchobanoglous, G., Burton, F. L., \& Stensel, H. D. (2003). Metcalf \& Eddy wastewater engineering: treatment and reuse. International Edition. McGrawHill, 4, 361-411.

UN-HABITAT, C. W. M. (2008). UN-HABITAT Water for Asian Cities Programme Nepal.

Usman, S., \& Santosa, I. (2016). Pengolahan Air Limbah Sampah (Lindi) dari Tempat Pembuangan Akhir Sampah (TPA) Menggunakan Metoda Constructed Wetland. Jurnal Kesehatan, 5(2).

Vymazal, J. (2005). Horizontal sub-surface flow and hybrid constructed wetlands systems for wastewater treatment. Ecological Engineering, 25, pp.478-490.

Vymazal, J. (2009). The use constructed wetlands with horizontal sub-surface flow for various types of wastewater. Ecological engineering, 35(1), 1-17. 